\title{
Revival of the Name Spiroplasmataceae fam. nov., nom. rev., Omitted from the 1980 Approved Lists of Bacterial Names
}

\author{
I. G. SKRIPAL' \\ Zabolotny Institute of Microbiology and Virology, Academy of Science of Ukr SSR, Kiev, U.S.S.R.
}

The name Spiroplasmataceae Skripal' 1974 was not included on the recently published Approved Lists of Bacterial Names and hence has no standing in bacteriological nomenclature. However, the name Spiroplasmataceae fam. nov. nom. rev. is herein revived for the organisms with which it was originally associated and many similar subsequently discovered organisms and by this action now has valid status. The type genus of Spiroplasmataceae is Spiroplasma Saglio, L'Hospital, Laflèche, Dupont, Bové, Tully, and Freundt 1973.

The name Spiroplasmataceae was validly published by Skripal' (5) before 1 January 1980 and was endorsed by the ICSB Subcommittee on Taxonomy of the Class Mollicutes (formerly ICSB Subcommittee on the Taxonomy of $\mathrm{Myco}$ plasmateles) (1). However, this name became invalid when it did not appear on the 1980 Approved Lists of Bacterial Names (4). Extensive study of members of this family since 1974 has strengthened the concept of a separate family for helical wall-less procaryotes (6). The purpose of this communication is to revive and reestablish validity of the name $S p i$ roplasmataceae for the organisms with which the name was originally associated and for many similar organisms subsequently discovered, as specified in Rules $27,28 \mathrm{a}$, and $33 \mathrm{a}$ and provisional rules B1, B2, and B3 of the International Code of Nomenclature of Bacteria (2).

Description. Cells bounded by a single membrane, with no evidence of cell wall, peptidoglycan, or precursor elements. Cells helical during logarithmic growth, with rotary, flexional, and translational motility, but may be spherical during stationary phase. Growth under aerophilic, microaerophilic or anaerobic conditions. Flagella or periplasmic fibrils not present, but intracellular fibrils have been demonstrated. Reduced nicotinamide adenine dinucleotide oxidase activity is located only in the cytoplasm. Growth on media containing mycoplasma broth base and horse or fetal bovine serum may require additional factors, such as amino acids. Defined media are available for some strains. Colonies frequently diffuse, reflecting the motility of cells in active growth. Colony type strongly dependent on agar concentration. Colony size varies from 0.1 to $4.0 \mathrm{~mm}$. Genome molecular weight, $10^{9}$. Guanine-plus-cytosine content of the deoxyribonucleic acid is 25 to $31 \mathrm{~mol} \%$. Strains possess a phosphoenol pyruvate phosphotransferase system for glucose. Acid produced during fermentation of glucose. Arginine is typically catabolized, especially in the presence of glucose. Unable to synthesize fatty acids from acetate. Most species are associated with arthropods or arthropods and plants, for which they may be pathogenic. Resistant to $10,000 \mathrm{U}$ of penicillin $\mathrm{G}$ per ml. Susceptible to erythromycin and tetracycline. Other characters as described for the class Mollicutes and the order Mycoplasmatales.

Type genus: Spiroplasma Saglio, L'Hospital, Laflèche, Dupont, Bové, Tully, and Freundt, 1973 (3).

\section{LITERATURE CITED}

1. Intermational Committee on Systematic Bacteriology, Subcommittee on the Taxonomy of Mycoplasmatales. 1977. Minutes of interim meeting, 22 September 1976. Int. J. Syst. Bacteriol. 27:392-394.

2. Lapage, S. P., P. H. A. Sneath, E. F. Lessel, V. B. D. Skerman, H. P. R. Seeliger, and W. A. Clark (ed.). 1975. International code of nomenclature of bacteria. 1975 Revision. American Society for Microbiology, Washington, D.C.

3. Saglio, P., M. L'Hospital, D. Lafleche, G. Dupont, J. M. Bove, J. G. Tully, and E. A. Freundt. 1973. Spiroplasma citri gen. and sp. n. A mycoplasma-like organism associated with "stubborn" disease of citrus. Int. J. Syst. Bacteriol. 23:191-204.

4. Skerman, V. B. D., V. MeGowan, and P. H. A. Sneath (ed.). 1980. Approved lists of bacterial names. Int. J. Syst. Bacteriol. 30:225-420.

5. Skripal', I. G. 1974. On improvement of taxonomy of the class Mollicutes and establishment in the order Mycoplasmatales of the new family Spiroplasmataceae fam. nova. Mikrobiol. Zh. (Kiev) 36:462-467.

6. Whitcomb, R. F. 1980 . The genus Spiroplasma. Annu. Rev. Microbiol. 34:677-709. 